\title{
INTRODUÇÃO A UMA EPISTEMOLOGIA DO USO
}

\author{
Arley Ramos Moreno*
}

\begin{abstract}
Em nosso texto, apresentando uma concepção de pragmática filosófica e tendo em conta uma exposição wittgensteiniana dos jogos de linguagem, pretendemos mostrar que a descrição terapêutica dos usos das palavras, através do procedimento de variações metodológicas de suas aplicações diversificadas, sugere uma série preciosa de elementos que permitem a exploração do conceito de uso como indicativo de um campo esclarecedor da atividade epistêmica de constituição da significação, através do trabalho com a linguagem e elementos do mundo extralinguístico. Desse ponto de vista, a atividade epistêmica não se limitaria a elaborar modelos cognitivos, mas deveria ser entendida como constitutiva da significação em geral, sendo as formas cognitivas um capítulo apenas, ainda que importante, da atividade mais geral de constituição que define o que é o objeto - ou melhor, define o seu sentido.

PalaVRAS-CHAVE: Wittgenstein. Pragmática filosófica. Epistemologia do uso. Terapia. Gramática.
\end{abstract}

\section{INTRODUÇÃO}

Já no Tractatus, Wittgenstein expressa a ideia de uma Teoria do Conhecimento como Filosofia da Psicologia, para contrastar o livro com as recentes teorias do conhecimento de sua época, a saber, a de Russell e de Moore. A reflexão sobre atos do pensamento que dizem respeito à lógica não deve ser psicológica, mas logicamente esclarecedora desses atos - eis a perigosa tarefa do livro, que corre o risco de ser confundido com uma análise psicológica, irrelevante para questões lógicas. Wittgenstein parece reconhecer, assim, que há um limite importante a ser observado entre os dois domínios de reflexão, mas que é, ao mesmo tempo, de difícil caracterização. As críticas que dirige a Russell expressam, pois, o cuidado que tem Wittgenstein, já nessa época, a respeito da lógica, de eliminar da reflexão filosófica qualquer elemento psicológico. Esta preocupação, herdada, certa-

* Doutor em Filosofia. Professor titular da Universidade Estadual de Campinas. Pesquisador do CNPq.

Cidade Universitária Zeferino Vaz. Barão Geraldo. 13083970. Campinas, SP - Brasil. Caixa-postal: 6110 arleymoreno2@gmail.com mente, do antipsicologismo de Frege, percorre toda a atividade filosófica de Wittgenstein até o final de sua vida, e está presente nos extensos comentários que faz sobre termos psicológicos em seus últimos escritos do final dos anos 40 .

Não somente antipsicologismo, mas, também, o antiempirismo fregeano continua marcando a trajetória de Wittgenstein, mesmo após o Tractatus, quando, então, a concepção de uso (gebrauch) afasta a descrição terapêutica de uma atividade socioantropológica que procurasse indicar causas para o comportamento. Tarefa de difícil execução, sobretudo após a autoterapia do formalismo essencialista do livro de juventude e o mergulho subsequente no solo árido do uso das palavras - que caracteriza a passagem do final dos anos 20 à década de 30 e o aprofundamento da nova concepção de significação. Será preciso demarcar do empírico não apenas o lógico, como, também, o que denominará, então, de gramatical.

De qualquer maneira, essas duas atitudes marcaram a trajetória de Wittgenstein sempre que ele refletiu sobre conceitos psicológicos envolvendo relações epistêmicas em geral, através da análi- 
se de sua expressão linguística, tais como, compreender, intencionar, querer dizer, ter expectativa, planejar, desejar, querer, reconhecer, identificar, saber, estar certo, duvidar e tantos outros. A tais atos, presentes em todos os campos da significação, Wittgenstein aplicou o procedimento de descrição terapêutica dos usos de palavras - lógica, matemática, linguagem, percepção de cores e de formas, relatos da percepção de sensações externas e internas, no passado, no presente e no futuro, etc. - através da discussão de concepções filosóficas tradicionais ou de opiniões do senso comum, das quais se trata de realizar a terapia. Reflexão filosófica que procura desfazer confusões do pensamento através do esclarecimento do sentido dos conceitos, e sempre evitando análises psicológicas e empíricas.

Por outro lado, e simultaneamente, há outra concepção constante na atividade filosófica de Wittgenstein, desde o primeiro livro até os escritos finais, que é a ideia de filosofia como prática de esclarecimento conceitual, e não como atividade de construção de teses. No período de juventude, os próprios esclarecimentos filosóficos do Tractatus têm, ao mesmo tempo, a função de crítica da linguagem e o estatuto de sequências linguísticas desprovidas de sentido e absurdas sendo justamente esse o resultado esclarecedor a que se queria chegar para o caso de todas as pretensas proposições significativas, mas que não possuem denotação, as pseudoproposições da metafísica. No período de maturidade, os esclarecimentos filosóficos passam a ter o estatuto de tratamento do pensamento, quando ele se encontra aprisionado por imagens unilaterais da significação. Com a ampliação do universo filosófico tractariano sobre a linguagem, não será mais a forma lógica, única e imutável, e nem a denotação das palavras que determinarão o estatuto teórico das legítimas proposições, demarcando-as das ilegítimas, mas, sim, as diversificadas aplicações das palavras que venham a compor contextos bem mais amplos do que a proposição, com relação ao nome, mas suficientemente circunscritos para serem reconhecidos como característicos de diferentes usos da linguagem - como ordenar e agir segundo as ordens, descrever um objeto pela aparência ou pelas suas medidas, e tantos outros jogos de linguagem, como os denomina Wittgenstein (IF § 23). Se pudermos, pois, falar em uma Teoria do Conhecimento como Filosofia da Psicologia, em Wittgenstein, ela será uma atividade exclusivamente esclarecedora de expressões linguísticas de atos do pensamento envolvidos em processos epistêmicos - duvidar, acreditar, estar certo, opinar, conhecer, etc. - e terapêutica das confusões geradas pela interpretação unilateral da significação dos conceitos relativos a esses atos segundo o modelo referencial. Essa teoria não deverá conduzir à construção de teses filosóficas a respeito do conhecimento e nem de atos mentais a ele relacionados - como os de dúvida, crença, certeza, opinião, etc. Após o Tractatus, com a ampliação pragmática da concepção de contexto linguístico, podemos pensar que uma filosofia da psicologia não mais seria um ramo da teoria do conhecimento, mas, pelo contrário, seria uma filosofia geral da significação linguística tendo como uma de suas partes a teoria dos conceitos epistemológicos. Essa última teria, em Wittgenstein, o caráter prático e terapêutico, demarcando-se de sua homóloga tradicional, de caráter tético.

A hipótese que gostaríamos de avançar, nesse ponto, é que a descrição terapêutica dos usos das palavras, através do procedimento de variações metodológicas de suas aplicações diversificadas, sugere uma série preciosa de elementos que permitem a exploração do conceito de uso como indicativo de um campo esclarecedor da atividade epistêmica de constituição da significação, através do trabalho com a linguagem e elementos do mundo extralinguístico. Desse ponto de vista, a atividade epistêmica não se limitaria a elaborar modelos cognitivos, mas deveria ser entendida como constitutiva da significação em geral, sendo as formas cognitivas um capítulo apenas, ainda que importante, da atividade mais geral de constituição que define o que é o objeto - ou melhor, define o seu sentido.

Essa mesma ideia está presente na concepção de gramática em Wittgenstein (IF § 373), no 
contexto, todavia, da concepção geral de filosofia como atividade exclusivamente terapêutica do pensamento, e não produtora de teses filosóficas. Desse ponto de vista, propriamente wittgensteiniano, o esclarecimento terapêutico viria pela apresentação das regras de uso das palavras, ou sua gramática, ao interlocutor cujo pensamento emaranhouse em confusões conceituais. O esclarecimento completo de uma dificuldade filosófica consistiria, então, em ver que o fundamento que se atribuía ao sentido nada mais é do que um fundamento convencional elaborado no processo de uso das palavras, sob a forma de regras normativas de sentido. A cura consistiria em admitir que o fundamento tradicional deva ser substituído por um fundamento linguístico, sem outro fundamento do que as técnicas envolvendo palavras, objetos do mundo exterior, estados mentais, ações entre interlocutores, e os mais variados aspectos das situações de interlocução, ou de aplicação das palavras. Assim, é a gramática que define o que é o objeto, e não algo exterior ao uso das palavras. Dessa maneira, fica relativizada a dieta unilateral advinda da aplicação exclusiva do modelo referencial da significação que a transporta para fora da linguagem. A tradicional questão ontológica sobre o que existe deverá ser respondida pelas regras da gramática do uso das palavras - como, p. ex., o que deve existir para que um nome possa ser aplicado é um instrumento da linguagem, uma norma linguística, um paradigma, e não algo que esteja fora da linguagem (IF.§§50-56). Esse é o resultado terapêutico a que se deve chegar através da descrição dos usos, tal como nos propõe Wittgenstein. Mas, para isso, será preciso, é claro, passar pelas minuciosas, e entediantes, como ele próprio o $\operatorname{diz}(B / F, \S 295)$, descrições de aplicações das palavras.

Ao sugerirmos uma reflexão epistemológica a partir da concepção de uso das palavras, estamos retirando o foco da função terapêutica que o conceito de uso possui em Wittgenstein e centrando nossa atenção sobre a função epistêmica do processo de constituição da significação. Como consequência, estamos introduzindo uma ideia de conhecimento que não é defendida como uma tese por Wittgenstein, embora esteja presente explicitamente em todos os processos terapêuticos de descrição dos usos. Trata-se de conceber o conhecimento como o conjunto das atividades correlativas de construção de relações internas de sentido e de sua aplicação, sob a forma de regras. Essa ideia de atividade epistêmica é colocada por nós como uma tese filosófica - o que Wittgenstein, como dissemos, não faria. Ora, a razão para não fazê-lo é que, segundo ele, teses limitam nossa percepção para apenas um aspecto dos objetos, aquele colocado por elas: cada tese se torna um sistema de referência a partir do qual passamos a julgar os objetos a serem descritos e, por consequência, a atribuir a eles propriedades que não lhes pertencem, mas que pertencem ao sistema de referência (CV, p. 21e22e, Ed.GH.von Wright, Revised Ed. A.Pichler, B.Blackwell, 1998). Daí a precaução exclusivamente terapêutica de Wittgenstein, com um fundo éticopara evitar, inclusive, o tão disseminado fascínio pelo modelo lógico da significação que o levara ao dogmatismo tractariano da juventude. Daí o nosso desafio: colocar teses que não sejam usadas dogmaticamente, por terem a descrição terapêutica como fonte de inspiração.

Construir regras de sentido significa, em outras palavras - e segundo o procedimento da descrição witttgensteiniana dos usos -, inventar, e mesmo criar, relações internas entre os objetos no interior de contextos técnicos, que são os jogos de linguagem, desde relações de inferência lógica presentes nas demonstrações e provas matemáticas até relações entre objetos sensíveis, como aquela que mantêm entre si duas cores, de mais claro e mais escuro, ou como de um objeto consigo próprio, como a identidade ou o número de letras de uma palavra, etc. Não são relações empíricas ou causais - por que se interessa a descrição do uso das palavras - mas de sentido, criadas na atividade linguística que envolve os mais diversos elementos das situações de interlocução e está, ao mesmo tempo, nelas envolvida - ou, como Wittgenstein os denomina, os jogos de linguagem. Essas relações de sentido são instituídas e aplicadas à experiência que é, assim, organizada signifi- 
cativamente: um algo se torna objeto de pensamento ao ser expresso linguisticamente através de conceitos - p. ex., manchas de cor passam a manter relações de sentido entre si, filiações e exclusões, combinações permitidas e outras excluídas, formando uma verdadeira geometria de um espaço das cores. Dados dos sentidos passam a ser expressos por conceitos e proposições relativos à percepção atual ou do passado, com os diversos graus de imprecisão inerentes ao seu sentido, formando o que podemos denominar, também, de verdadeiras geometrias do espaço visual e da percepção mnemônica; da mesma maneira que fatos futuros passam a ser antecipados por estados mentais, como expectativas, intenções, previsões, desejos, etc., formando, assim, verdadeiras geometrias de modalidades, do possível, provável, virtual e necessário. Em todos os casos, não se trata de relações empíricas entre pensamento e seus conteúdos, mas de relações internas, ou de sentido, entre pensamento e realidade - relações que possuem a marca da necessidade, e não da contingência. Essa atividade de organização linguística da experiência por constituição do sentido perpassa todas as descrições do uso que realiza Wittgenstein, e é ela que qualificamos, neste texto, de atividade cognitiva: conhecer é construir regras de sentido e operar com elas, aplicando-as aos objetos de pensamento.

Nesse ponto, como veremos melhor, há uma diferença importante entre essa concepção de conhecimento que acabamos de introduzir, extraída da prática terapêutica, e aquela concepção que Wittgenstein descreve como presente nas aplicações normais que fazemos desse conceito - e que ele próprio considera como um parâmetro para realizar a terapia de certas aplicações confusas -, a saber, todo conhecimento é um conteúdo que deve poder passar pela prova dos fatos, ou cuja expressão proposicional deva poder ser falseada com sentido: p expressa um legítimo conhecimento apenas se a sua negação tiver sentido, i.e., se for possível que p seja falseável dentro de condições normais de sua aplicação. Ora, desse ponto de vista, as relações internas não são conhecimento, mas normas de sentido que, por assim dizer, antecedem o conhecimento, fornecendo o seu contexto conceitual e sua condição de significação. Assim, não estamos tentando descrever aplicações de palavras, à maneira de Wittgenstein, i.e., para fins terapêuticos, mas, sim, propondo uma concepção de conhecimento a partir de alguns dos resultados dessa sua descrição.

Tentaremos esclarecer quais são esses resultados e por que nos parecem pertinentes para realizar a empreitada de uma Teoria do Conhecimento, não mais em estilo logicista, como no Tractatus, mas pragmático.

\section{UMA CONCEPÇÃO DE PRAGMÁTICA}

Seria importante distinguir, logo de início, uma concepção filosófica de pragmática, tal como pretendemos extrair do conceito de uso em Wittgenstein, de outras concepções oriundas, sobretudo, da tradição norte-americana, mas com desenvolvimentos no pensamento europeu atual. Da primeira tradição, podemos elencar James, Dewey e, mais recentemente, Quine e Rorthy reservando um lugar especial a Peirce, que enfatizava sua desvinculação do pragmatismo jamesiano da sua época. De fato, não são critérios empíricos, tais como a utilidade e a natureza, que determinam a verdade de uma ação ou de uma proposição, mas, como diz Wittgenstein, invertendo essa relação de determinação, é a verdade que determina a utilidade de uma ação ou proposição, assim como, também, o seu sentido não é determinado por elementos naturais, mas é autônomo com relação a tais elementos e, mesmo, pode conservar-se inalterado no uso das proposições, a despeito de situações contrafactuais que possam ser encontradas: p.ex., ainda que certos fenômenos da natureza apresentem um comportamento que desafie o principio da não-contradição, como os quanta de energia no interior do núcleo dos átomos, mesmo assim não abriremos mão desse princípio em sua aplicação aos objetos da experiência cotidiana - pelo contrário, tentaremos solucionar 
as contradições empíricas construindo modelos lógicos que as assimilem e reelaborem metalinguisticamente, como as lógicas quânticas e as paraconsistentes.

Dentre os mais destacados representantes europeus atuais do pragmatismo, podemos citar os professores Habermas e Appel. Nesse caso, as concepções do pragmático estão fundadas em teorias pragmáticas linguísticas da linguagem, ainda que inspiradas em sistemas filosóficos. De fato, é o modelo pragmático de Grice, com sua teoria das implicaturas conversacionais de inspiração transcendental kantiana, que, por sua vez, inspira as concepções de pragmática dos pensadores germânicos. Trata-se, para eles, de procurar fundamentos para a comunicação e para a ética em uma razão dialógica comunicativa e em uma razão cooperativa, ambas transcendentais - cuja natureza pragmática é fornecida pelo modelo da teoria linguística das implicaturas de Grice.

Ora, no caso de uma pragmática em estilo wittgensteiniano, contrariamente ao pragmatismo norte-americano, o sentido atribuído às ações e proposições é autônomo, relativamente a critérios empíricos, sociológicos e naturais, assim como, contrariamente ao pragmatismo europeu, não há lugar teórico, dialógico intersubjetivo ou transcendental puro, que possa garantir a harmonia da comunicação e a cooperação intersubjetivas universais, uma vez que as diferentes imagens de mundo podem sempre estar em conflito irredutível quanto a seus domínios de sentido.

A pragmática filosófica, tal como pretendemos apresentá-la, seria herdeira do pensamento de Frege e, ao mesmo tempo, teria como inspiração a descrição dos usos da linguagem feita por Wittgenstein. Por um lado, uma pragmática derivada do projeto fregeano da ideografia corresponde à exploração dos três domínios que Frege descartou minuciosamente desse seu projeto - aliás, exploração realizada a partir do início do século XX por filósofos e por linguistas -, a saber, das expressões linguísticas (a) cujo sentido não possui apenas conteúdo verifuncional, mas também, por outro, o que Frege denominou de força (Kraft), (b) cujo sentido ultrapassa esse mesmo conteúdo como, p. ex., as expressões linguísticas de estados psicológicos, e aquelas (c) cujo sentido estritamente linguístico é insuficiente para que se possa determinar o seu conteúdo verifuncional - como no caso dos dêiticos e pronomes pessoais.

É assim que, nos estudos da linguagem, encontramos algumas formulações gerais do campo da pragmática que o situam, relativamente e por oposição, nos campos da semântica e da sintaxe - p. ex., em Morris (1938) e em Carnap (1942) - como marcada pela presença empírica dos interlocutores e das situações de enunciação. Em contraposição a essa caracterização empiricizante do campo da pragmática, parece-nos que o conceito wittgensteiniano de uso da linguagem permite concebê-lo como marcado por regras formais e $a$ priori, estabelecidas, todavia, a parte post. A inspiração na atividade filosófica de Wittgenstein consiste em salientar as duas funções exercidas pelas regras pragmáticas. Primeiro, organizar a experiência identificando e diferenciando os seus elementos pela atribuição de nomes; é o que poderíamos denominar de função reguladora da regra, uma vez que permite selecionar previamente os elementos da experiência de acordo com a possibilidade de atribuir-lhes um nome. Segundo, definir o sentido do conceito dizendo o que é o objeto assim nomeado. Seguindo a inspiração kantiana, podemos falar, nesse caso, de função constitutiva das técnicas linguísticas pragmáticas que surgem no decorrer das descrições das aplicações das palavras. Ora, parece-nos que essas técnicas são realçadas pelo filósofo-terapeuta enquanto organiza simbolicamente a experiência pela atribuição de nomes, preparando o momento da constituição do sentido, e não enquanto possam ter a função empírica ou causal sobre a sua determinação. Por exemplo, o gesto ostensivo pode ser a causa para que olhemos o objeto apontado e pronunciemos o seu nome; todavia, esse mesmo gesto desempenha, também, a função de atribuir uma identidade ao objeto apontado pela aplicação a ele da palavra pronunciada, i. e., através da expressão linguística que permitirá doravante identificá-lo. Em seguida, 
trata-se de definir o sentido do nome assim atribuído e dizer o que é o objeto.

A sintaxe e a semântica correspondem a organizações formalizáveis do sentido em estruturas abstratas, mas não a domínios de constituição do sentido. Os processos de constituição não são nem sintáticos e nem semânticos, mas pragmáticos, como o mostra a descrição wittgensteiniana dos usos da linguagem, ao apresentar exemplos de técnicas diversas de operar com as palavras que estão na base da constituição do sentido. Desse ponto de vista, ela aponta, acreditamos, para uma perspectiva epistemológica que está além de sua função terapêutica - embora seja essa a única que interessou a Wittgenstein explorar.

\section{UMA VISÃO PANORÂMICA DA EXPLORAÇÃO DOS USOS DA LINGUAGEM}

O procedimento de descrição dos usos das palavras explora, grosso modo, três domínios de reflexão: os jogos filosóficos, que dão margem à construção de sistemas metafísicos por não se darem conta de que lidam apenas com regras de sentido, ou, conforme Wittgenstein, com a gramática de expressões linguísticas; os jogos normativos e os descritivos, nos quais as palavras e expressões linguísticas são aplicadas, respectivamente, ou apenas como regras de sentido, ou como descrições de processos factuais; são jogos que introduzem normas, os valores de verdade e critérios de comparação com o mundo extralinguístico. E, finalmente, os campos das técnicas preparatórias e das técnicas constitutivas do sentido presentes nos jogos de linguagem normativos e descritivos. Trata-se de explorações complementares que enfatizam cada um dos aspectos a cada incursão da terapia i.e., relativamente ao tipo de interlocução, seja o mentalismo, o behaviorismo, o logicismo, o idealismo, o empirismo, o ceticismo, etc. -, sendo esse procedimento mais notável na obra melhor acabada de Wittgenstein, as IF, com seu estilo de álbum.

Seria interessante partirmos de um ponto de vista panorâmico sobre esses três domínios de exploração da descrição dos usos, que é o que gostaríamos de chamar de o enigma de Agostinho, tal como é evocado por Wittgenstein (IF § 89): por que sabemos certas coisas quando não nos perguntam sobre elas, e não mais sabemos quando precisamos explicá-las? Por que não refletimos (besinen) sobre essa questão? Podemos considerar que grande parte do esforço de Wittgenstein após o Tractatus e, de maneira sistemática, a partir dos anos 30, consiste em refletir e aprofundar-se sobre essa questão enigmática colocada por Agostinho e retomada por ele no contexto da autoterapia de sua fase logicista. A resposta é a seguinte: criamos teorias por razões para explicar a essência do que tem sentido - p. ex., a essência do tempo, segundo Agostinho -, quando nos perguntam, e, com isso, perdemos de vista o que sabíamos antes de nos perguntarem - e que continuamos sabendo, mas deixamos de perceber - isto é, as aplicações efetivas que fazemos das palavras, por exemplo, da palavra "tempo" (p. ex., DW/S 'Zeit' p. 266267, F 64). As aplicações das palavras são veladas pelas teorias da essência de seu sentido. Essa é uma dificuldade exclusiva da filosofia, e não uma dificuldade da ciência. De fato, em nossas formas de vida, talvez seja mais importante e difícil saber o que é o tempo do que quais são suas causas, uma vez que essa segunda pergunta pode ser respondida por diferentes modelos científicos provisórios e falseáveis, enquanto que a primeira solicita uma reposta única e definitiva. Ao procurar explicações únicas e definitivas, pela indicação da essência, a filosofia leva a dificuldades infindas, impedindo-nos de ver o que está à nossa frente quando usamos os conceitos, a saber, as aplicações das respectivas palavras em situações específicas de uso da linguagem. A diversidade de aplicações contrasta com a suposta exclusividade do que deve ser a essência do conceito - assim como a diversidade de objetos triangulares empíricos contrasta com a essência conceito de triângulo, como já haviam notado os antigos filósofos gregos, dentre os quais Platão, evocado por Wittgenstein, com frequência, como exemplo desse tipo de dificuldade.

Essa dificuldade é explicitada ao longo dos 
anos 30, e está presente nas $I F$ sob a forma de mostrar e ser capaz de ver aspectos do sentido conceitual - velados pelo pensar segundo uma teoria - passando a ser tarefa exclusiva da atividade filosófica esclarecer a seguinte situação: a dificuldade de não poder senão ver como segundo um único aspecto, e não simplesmente ver a diversidade de usos das palavras ao pensar não reside, na verdade, no entendimento, como parece ser sugerido a partir do exemplo de Agostinho sobre o tempo, mas na vontade - como notara Wittgenstein já na época dos textos que compõem o Big Typescript. Daí a dimensão terapêutica que passa a ter a atividade filosófica de descrição dos usos das palavras, tanto dos indivíduos quanto das questões filosóficas gerais que os afetam. Os interlocutores presentes no álbum, as $I F$, assim como nos escritos finais sobre filosofia da psicologia, sobre cores e sobre a certeza, são afetados pessoalmente pelas teses realistas ou idealistas, empiristas ou formalistas, behavioristas ou mentalistas que defendem, e a cura deve proceder caso a caso, como uma terapia de indivíduos, não para combater dificuldades psicológicas pessoais, mas dificuldades filosóficas tradicionais presentes no que dizem os indivíduos ao pensar sobre os fundamentos do sentido. Nosso apego a razões nada tem de intelectual, mas de volitivo, uma vez que razões, mais do que explicar, justificam (rechtfertigen) o que é a essência, mas não são capazes de provar - fora da ciência, não é possível provar através de ligações entre argumentos cujas regras de verificação e de construção de hipóteses sejam dadas previamente, sob a forma de um método único. Não podemos provar, por exemplo, o que é o tempo, mas apenas tentar apresentar razões persuasivas sobre a sua essência. Ou, então, fora da filosofia, podemos apresentar modelos explicativos e provisórios sobre o tempo. Ora, como ao filósofo interessa a essência e, por isso, respostas definitivas que justifiquem o sentido, a terapia filosófica seria um tratamento da cegueira para os diferentes aspectos do sentido dos conceitos, o que não comporta uma resposta definitiva, mas, sim, a apresentação de perspectivas sobre a diversidade de aplicações conceituais Por isso, a fonte principal dessa doença é a vontade, e não o intelecto, e o tratamento para ela não será a aplicação de um único método, mas procedimentos terapêuticos.

Essa é a tarefa exclusiva da atividade filosófica que propõe Wittgenstein ao explorar os jogos de linguagem filosóficos, os jogos normativos e os descritivos e as técnicas preparatórias e as constitutivas do sentido presentes nos usos das palavras.

Olhemos, agora, o horizonte para o qual nos apontam os resultados dessa atividade, a partir dos diversos procedimentos terapêuticos.

\section{DOMÍNIOS DA DESCRIÇÃO DOS USOS}

A descrição dos usos da linguagem leva Wittgenstein a refletir sobre várias questões tradicionais da filosofia e a sugerir análises originais para questões na área da epistemologia, análises, como veremos, de natureza pragmática. Podemos organizar essa descrição wittgensteiniana dos usos, indicando alguns de seus principais percursos e os domínios que, assim, vão sendo colocados em relevo. Sendo terapêutica a motivação central da descrição, trata-se sempre de cumprir pelo menos três tarefas principais: situar as confusões conceituais, diagnosticar as suas fontes e, finalmente, fornecer um tratamento para elas. Éassim que são fortemente marcados os três domínios de reflexão mencionados acima: os jogos filosóficos, as funções normativa e descritiva da linguagem e as técnicas linguísticas reguladoras e constitutivas do sentido.

\section{OS JOGOS FILOSÓFICOS}

Jogos de linguagem podem ser qualificados de filosóficos em, pelo menos, dois sentidos principais. Por um lado, há aqueles que manipulam proposições consideradas necessárias - tais como, "o tempo é o fluxo entre passado, presente e futuro", "todo objeto é idêntico a si próprio", “o todo é maior do que suas partes", "toda palavra possui o 
número de letras que a compõem”, “esta mão é minha mão (ao mostrar-se a mão própria)”, "toda sensação é privada", etc. - e interpretam a necessidade como algo que corresponde a entidades extralinguísticas e extraconvencionais, construindo, assim, sistemas metafísicos: por aplicarem o modelo referencial da significação partem à busca de tais entidades metafísicas, ou quimeras, como diz Wittgenstein (IF § 94). Nesse sentido, os jogos filosóficos são geradores de confusões conceituais e constituem, por isso, a matéria-prima da terapia wittgensteiniana.

Por outro lado, a própria atividade descritiva dos usos, que pretende ser curativa dessas confusões, também pode ser considerada como um jogo de linguagem, por relacionar palavras, circunstâncias e ações, levando em conta as formas de vida em que estão inseridas. Esse jogo pode ser qualificado de filosófico, na medida em que, atendo-se ao sentido dos conceitos, não às suas causas, também se interessa por proposições necessárias, mas, agora, para mostrar que confusões a respeito da necessidade podem ser dissolvidas quando se observa a função constitutiva exercida pelos sistemas complexos de regras de uso da linguagem, com respeito ao sentido. Desse segundo ponto de vista, o jogo filosófico não propõe teses sobre a realidade, ou sobre o que é o objeto e o que existe - contrariamente aos jogos filosóficos que procura esclarecer. É a função autocrítica, ou, na terminologia de Wittgenstein, autoterapêutica da atividade filosófica, ao voltar-se para si e questionar seus próprios fundamentos.

O mais importante seja, talvez, a ideia de que o tratamento para essas confusões não pode ser encontrado nas ciências, mas, exclusivamente, na própria filosofia. Um modelo científico do tempo, por exemplo, não poderá substituir satisfatoriamente uma interpretação filosófica da essência do tempo e, por isso mesmo, o próprio cientista será levado, mais cedo ou mais tarde, a engajar-se em uma interpretação essencialista, usando-a como pano de fundo do modelo científico para dar-lhe, como que um sentido mais amplo e profundo, sempre ausente do modelo. É quando o cientista da natureza passa a falar, como diz Wittgenstein, sobre a existência e a realidade metafísica dos modelos e conceitos que criou para explicar os fatos do mundo, ou mesmo o matemático, ao se deslumbrar com a realidade metafísica de um universo novo de objetos matemáticos, aberto à sua frentecomo Cantor, face ao universo dos números transfinitos. Nesses momentos, o próprio cientista assume o discurso confuso da filosofia, em seu primeiro sentido, e passa a fazer filosofia da natureza ou da matemática. Fica claro, então, que um novo modelo científico não poderá eliminar essas confusões filosóficas do próprio cientista - confusões também presentes, aliás, ainda que de maneira menos sistematizada, no discurso do senso comum a respeito das trivialidades consensuais da vida cotidiana, tais como "esta mão é minha" e "este nome é meu".

A terapia proposta por Wittgenstein não constrói novos sistemas de teses sobre realidades metafísicas, mas apenas esclarece as confusões presentes nesses sistemas pela detecção de sua fonte principal. Ora, a fonte geradora das confusões é, por sua vez, esclarecedora das funções epistêmicas que se encontram em jogo no processo de elaboração do sentido conceitual: a posição da norma e a definição do objeto. Como veremos, essa será uma perspectiva aberta pela descrição dos usos da linguagem, para além da terapia.

\section{AS FUNÇÕES NORMATIVA E DESCRITIVA}

Uma das mais profundas lições da terapia parece-nos ser a ideia de que, no uso da linguagem, i.e., nos processos de aplicação das palavras e das proposições, é que são constituídas as relações entre linguagem e mundo. Ela nos mostra a natureza gramatical, e não mais ontológica, do abismo entre os dois domínios - considerado, na tradição filosófica, intransponível para a razão, mas transponível factualmente e, por isso, incognoscível e fadado ao reino do mistério. Mostra-nos, ao contrário dessa tradição, que há ligações internas, ou de sentido, entre os domínios empírico e simbóli- 
co realizadas pelos processos de uso da linguagem - ao mesmo tempo, necessárias e convencionais. A dificuldade tradicional da metafísica é como que "dissolvida" (lösen) (IF § 109) pela ideia de gramática dos usos da linguagem - na medida em que mostra o papel do trabalho de organização linguística da experiência na integração do empírico nessa organização. A descrição dos usos mostra que atribuir funções simbólicas ao empírico faz com que ele opere como regra normativa nos processos de organização da experiência, sendo incorporado, assim, à linguagem como um de seus instrumentos - tal é, como mostra Wittgenstein, a função dos retratos (Porträt), das amostras (Muster), dos paradigmas (Paradigma) usados como padrão (Moreno, 2011).

A fonte das dificuldades filosóficas seria eliminada e, com isso, não mais haveria razão para levantá-las, caso o pensamento não recaísse em certas interpretações confusas que fazemos dos usos da linguagem. Todavia, a própria atividade filosófica de Wittgenstein é o melhor exemplo de tais recaídas - daí, aliás, o aspecto autoterapêutico nelas presente até o final de sua vida.

De fato, o percurso de Wittgenstein para chegar àquela solução passa pela admissão, nem sempre muito clara, de que as palavras e proposições exercem diversas e diferentes funções que não estão inscritas em sua natureza, mas são atribuições dos usos que delas fazemos. Uma boa ilustração da dificuldade em percebê-lo está na difícil passagem da concepção de proposição como imagem descritiva à concepção de proposição como imagem convencional da necessidade, isto é, à função gramatical da proposição. Essa dificuldade permaneceu, certamente, uma fonte de preocupação até o final de sua vida, uma vez que a questão central nela envolvida é a da autonomia do sentido, agora, do ponto de vista da gramática, ou melhor, das regras de sentido engendradas no uso da linguagem (Moreno, 2012). Vejamos, com mais detalhes, alguns aspectos da dificuldade para alcançar uma visão clara tanto da diversidade de funções da linguagem, quanto, e sobretudo, de suas diferenças quando das aplicações.

\section{UNIFORMIDADE SUPERFICIAL DA LINGUA- GEM E FLUTUAÇÃO ENTRE OS USOS}

Há três dificuldades à visão clara da multiplicidade de funções da linguagem - e, em particular, da diferença entre a função descritiva e a normativa que as proposições exercem em certos casos de suas aplicações. Primeiro, há a uniformidade superficial entre os elementos da linguagem - o que nos leva a generalizar uma função em detrimento de outras, como assinala Wittgenstein autoterapeuticamente (IF §§ 11,12, sgs.). Por exemplo, segundo o Tractatus, a forma geral da proposição é "isto está assim e assim", que é a forma geral da descrição de fatos - como se a linguagem exercesse, apenas e essencialmente, a função descritiva. Segundo, a flutuação entre as aplicações que fazemos das proposições, ora como descrições, ora como normas de sentido, torna difícil ver claramente a função que está em jogo a cada situação. Essa segunda dificuldade é agravada pela primeira, na medida em que for salientada a forma descritiva da proposição, pois, nesse caso, torna-se ainda mais difícil perceber que uma proposição de forma descritiva nada esteja descrevendo, mas, pelo contrário, esteja exercendo a função normativa - como bem o mostra Wittgenstein em seu último Manuscrito, sobre a Certeza. Eis as duas dificuldades que nos levam a aderir ao modelo referencial (Bezeichnung) para responder à pergunta agostiniana sobre a significação dos conceitos: é a referência das palavras e dos conceitos o que explica sua significação.

Todavia, novas dificuldades surgem, quando não encontramos a referência e formos obrigados a criar teorias filosóficas para justificar (rechtfertigen) a significação. Será esse, como sabemos, o tema da terapia, e, sobretudo, da autoterapia.

É durante o intenso percurso da concepção essencialista de proposição como imagem isomorfa aos fatos que descreve à visão terapêutica dessa concepção, que Wittgenstein reconhece a multiplicidade de funções que a proposição pode exercer e considera que a concepção essencialista é uma imagem - agora no sentido criticado por 
ele, de supostamente expressar a superordem entre superconceitos - da qual é preciso realizar a terapia. (Moreno, 2011). A concepção tractariana de que há uma forma lógica, essencial e única da proposição, que é a forma geral de toda descrição de fatos, será, posteriormente, relativizada à definição construída no interior do jogo de linguagem particular em que se aplica o cálculo verifuncional.

Pelo contrário, dirá então Wittgenstein autoterapeuticamente, um aspecto importante de nosso conceito de proposição é o "soar como uma proposição” (Satzklang) (IF §§ 134-136). Em outras palavras, e generalizando a mesma ideia a todos os elementos da linguagem, cabe ao uso determinar o que será considerado proposição, ou nome, nos diferentes jogos de linguagem - afastando, assim, a concepção de uma propriedade única e essencial, inerente à proposição ou ao nome (IF § 49). O conceito de proposição deixa de ser considerado um superconceito e torna-se equivalente a conceitos triviais, como o de jogo, isto é, um conceito cujos limites são imprecisos, determináveis apenas nas suas aplicações - e não mais a priori.

Assim, a terapia da concepção essencialista e unilateral de proposição, como eminentemente descritiva, conduz Wittgenstein a reconhecer que, no caso de expressões linguísticas que descrevem situações que parecem não poder ser negadas - com o risco de gerarem contradições ou perderem o sentido, como diz Wittgenstein, de "superexpressões" ou "superlativos filosóficos” (IF § 192) que supostamente descreveriam a "superordem" entre "superconceitos” (IF § 97) - não se trata, na verdade, de descrições, mas apenas de proposições aplicadas como normas, ou padrões de sentido, ou, mais amplamente, como critérios de referência para a ação linguística. São proposições aplicadas gramaticalmente, ou melhor, que perdem a força e a profundidade das imagens filosóficas, conservando apenas a necessidade das convenções. Essa é a difícil mudança de vontade que almeja realizar a terapia da concepção essencialista de significação. Como diz Wittgenstein a esse respeito: “À profundidade que vemos na essência corresponde a necessidade profunda da convenção.” (BGM I, § 74).
A vontade deve ambientar-se no novo contexto pragmático, com o atrito da ação linguística.

\section{AUTONOMIA DO SENTIDO EM UM AMBIENTE PRAGMÁTICO}

A terceira dificuldade, mais ampla, para uma visão clara da diversidade de funções da linguagem vem do ambiente pragmático, em que ações, interlocutores e objetos do mundo exterior e interior passam a contar como critérios e como regras linguísticas. Torna-se mais difícil perceber a independência do sentido com relação a esse conjunto de elementos, do que, no ambiente logicista, a autonomia da forma lógica. No espaço dos usos da linguagem, são afirmadas a autonomia e a arbitrariedade da gramática (BT 238) - assim como, no espaço a priori das funções de verdade, eram afirmadas a autonomia e a necessidade da lógica. A dificuldade parece ser bem maior, após o Tractatus, do que antes, uma vez que, se o método de análise lógica permitia revelar a forma profunda e única da linguagem, não há, no ambiente pragmático, qualquer método especial que permita mostrar a diversidade de suas formas profundas (IF § 664) a gramática dos usos. Nesse segundo caso, há apenas diversos procedimentos de descrição dos usos das palavras e das proposições - e, ainda assim, com finalidade estritamente terapêutica, dirigidos apenas à cura do pensamento, e não mais também epistêmica, tal como poderia ser interpretada a crítica da linguagem tractariana. Na ausência de um método, Wittgenstein admite que sejam desenvolvidos diferentes procedimentos de descrição para cada tipo de caso - diferentes comparações e exemplos de aplicação das palavras, diferentes analogias, diferentes casos intermediários, etc.

Entretanto, a ausência de um método único revela que, nesse ambiente pragmático, não se poderia esperar que houvesse uma única forma essencial da linguagem, como que à espera do bom método. Pelo contrário, há tantas formas quantos forem os casos de aplicações das palavras e proposições. E aqui reside, certamente, a maior dificul- 
dade: detectar os usos em sua enorme diversidade, sem levantar perspectivas generalizantes, ou teorias explicativas. As formas de vida nos permitem, sem dúvida, levantar expectativas, mas não justificam formular sistemas prévios de regras fixas à maneira de uma sua sintaxe lógica. Como mostra Wittgenstein, mais uma vez, em seus últimos textos sobre a certeza, ausência de exatidão não implica ausência de limites, ainda quando houver flutuação entre eles - como em um rio, entre as correntes e o leito. Há limites, embora vagos e bastante amplos, para as formas de vida, limites fornecidos pela Imagem de Mundo (Weltbild) presente em cada cultura - fora dos quais as ações perdem o sentido, ou passam a ser consideradas como heresia, engano, loucura (Moreno, 2004). De qualquer maneira, é nas aplicações que os contornos vagos das regras são fixados, relativamente aos contextos e situações no interior de cada jogo: a vagueza inicial de uma regra não implica a ausência de limites, que serão identificados e, mesmo, estabelecidos, à medida que jogamos um jogo, isto é, a parte post, ou, ainda, como diz Wittgenstein, as we go along (IF § 83).

A dificuldade maior está, agora, em admitir que criamos e inventamos a necessidade enquanto elaboramos novos sentidos e novas regras, sem uma direção previamente estabelecida para essa criação e invenção - como se a necessidade não pudesse repousar senão em um solo firme prévio e independente das vicissitudes da ação. Dificuldade da vontade, mais do que do intelecto, em admitir que a firmeza do solo possa ser adquirida durante o processo de aplicação da regra - assim como a firmeza das paredes de um edifício é fornecida por tudo o que elas suportam, bem mais do que por suas fundações que a precedem (Certeza § 248). A multiplicidade e a imprevisibilidade dos usos da linguagem é a fonte da autonomia e, por consequência, da arbitrariedade da gramática. Ideia difícil, certamente, de admitir, sobretudo por parte de um herdeiro do pensamento logicista de Frege e Russell - para quem a autonomia da lógica vem de sua necessidade a priori (Tr p.ex. 5.473, sgs.). Como ele próprio o diz: "Aquilo sobre o que escrevo tão tediosamente pode ser óbvio para alguém cuja mente é menos viciada.” (BF § 295).

Foi preciso, de fato, vencer algumas das dificuldades deixadas em aberto pelo Tractatus para que Wittgenstein pudesse libertar-se das Imagens (Bild) que habitavam o seu pensamento a respeito das ligações entre pensamento e linguagem através da proposição como imagem dos fatos (Bild).

\section{ANOMEAÇÃO}

Wittgenstein organizou a parte inicial do álbum em torno e na sequência de dois temas complementares, herdados do Tractatus, que são dois aspectos do processo de organização linguística da experiência através de atribuição de nomes. Em primeiro lugar, o tema dos pontos de contato entre a linguagem e a realidade, ou as antenas com que a proposição toca a realidade (Tr.2.1515), e, em segundo lugar, o da natureza e constituição da significação proposicional. Esses temas são retrabalhados nas Investigações, nessa mesma sequência, sob a forma do ensino ostensivo das palavras (hinweisendes Lehren der Wörter), ou adestramento (Abrichtung), e do esclarecimento ostensivo, ou definição (hinweisende Erklärung‘ oder 'Definition' (IF § 6).

De fato, a questão da nomeação será desmembrada e apresentada sob dois aspectos. Primeiro, os pontos de contato elementares da linguagem com a realidade, que serão, agora, atribuídos a técnicas de ensino ostensivo, ou de adestramento, inseridas em situações que orientam a sua aplicação, isto é, as lições (Unterricht) de que fala Wittgenstein (IF § 6). São essas lições que permitem interpretar os gestos ostensivos e as repetições de palavras, e aplicá-los seja para adestrar o comportamento, seja para associar imagens mentais a objetos, seja mesmo para facilitar a compreensão da palavra (IF § 6). Assim, a mesma técnica cumprirá funções diferentes de acordo com a lição em que for apresentada. A ênfase é dada aqui ao fato de o aprendiz já dominar algumas das diversas atividades que podem ser realizadas com um 
nome, além da função referencial que lhe é tradicionalmente atribuída, para saber o lugar da palavra nessa sua aplicação como etiqueta - por exemplo, para nomear a forma e não a cor, etc. (IF §§ 7-27).

O segundo aspecto da nomeação diz respeito à definição do nome, ou ainda, à pergunta pelo sentido. Da mesma maneira, a ênfase é colocada no fato de a definição só esclarecer o uso do nome quando o aprendiz já dominar diversos jogos com a respectiva palavra, isto é, quando já lhe for claro o papel que a palavra desempenha na linguagem, ainda que sem conhecer explicitamente suas regras - por exemplo, ao olhar e imitar pessoas jogando (IF §§ 28-34).

Nos dois casos, tanto a introdução do aprendiz ao sentido através da nomeação, quanto através da pergunta pelo sentido do nome, é suposta a sua familiaridade prévia com o uso das palavras, sua inserção em diferentes lições; ou melhor, tanto para aprender a nomear quanto para ser capaz de perguntar sobre o nome, ele deve dominar previamente outras técnicas que envolvem a linguagem. Dominar (beherschen) previamente algumas técnicas permite ao aprendiz interpretar, e não apenas reagir a novas instruções que lhe forem dadas; é o que o torna capaz de ver relações de sentido, além de relações empíricas, ao ser afetado por estímulos. Em outros termos, o aprendiz será capaz de compreender novas técnicas e aplicá-las adequadamente (p.ex. IF § 33). Será capaz, por exemplo, de distinguir entre a aplicação do nome como etiqueta, ou exclamação, ou pedido, ou apelo, ou evocação de imagens mentais, etc. (IF § 27).

O domínio prévio de técnicas linguísticas por parte do aprendiz é o pano de fundo suposto pela descrição do uso e seu ponto de partida. De fato, é ele que permite ao terapeuta descartar a descrição de relações empíricas entre linguagem e mundo - isto é, as associações mecânicas ou causais entre sons e objetos - assim como a formulação de hipóteses a respeito de processos de aquisição e aprendizagem. Ora, como vimos, a introdução do aprendiz no uso da linguagem pode ser feita de diversas maneiras, desde o adestramento - que estabelece associações iniciais entre palavras e objetos, ou entre palavras e imagens mentais através de regras -, ou por observação de aplicações dos signos e sua imitação, introjetando comportamentos e ações inseridos em jogos de linguagem, até, em outra etapa e explicitamente, pela definição do sentido de conceitos. Daí a importância teórica, e também estratégica, de apresentação inicial, no texto das Investigações, da questão das ligações entre linguagem e realidade envolvendo a nomeação, pois aí estão presentes as técnicas introdutórias do aprendiz nos jogos de linguagem e a elaboração da relação de familiaridade com os usos das palavras. O aprendiz é treinado a ver relações internas, uma vez que a familiaridade com diversos jogos consiste em desenvolver a habilidade de compará-los entre si e aprender a ver semelhanças entre casos diferentes, usando, para isso, a linguagem. Por exemplo, a ligação interna de sentido entre comportamentos tão diferentes, como as manifestações de ansiedade e as de satisfação, pode ser dada pelo conceito de expectativa (p.ex. IF § 444; Z § 57). É assim que podemos ser introduzidos nos jogos de linguagem, e é aí que a descrição terapêutica colhe a sua matéria-prima bruta, a vivência da significação das palavras, e sua complementar, a cegueira para a significação (p.ex. IF II, xi).

A exposição desses dois aspectos da nomeação precede, nas $I F$, a questão que fora central no Tractatus, da essência da proposição e do pensamento (IF §§ 65-94), inserindo-a, então, no contexto pragmático do uso da linguagem. Essa ordem de apresentação parece-nos corresponder ao esforço de Wittgenstein para enfrentar as dificuldades legadas pelo livro de juventude, reconhecendo sua importância e respeitando sua prioridade conceitual. ${ }^{1}$

\footnotetext{
A organização das IF sob a forma de um “álbum”, com repetições dos mesmos temas a partir de diferentes pontos de vista, pode ser bem apreciada nesse caso. De fato, observe-se que o tema geral da nomeação, e sub-temas correlatos, estende-se até o parágrafo 87 , sendo seguido, após breve transição, pelo tema da definição de conceitos e sua expressão proposicional, e subtemas correlatos, a partir dos parágrafos 89-92. É como se temas apresentados anteriormente em detalhes fossem retomados de perspectivas cada vez mais amplas, ficando, assim, refletidos e sendo aprofundados nas apresentações seguintes. A complexa ordem linear de apresentação dos aforismos no Tractatus, indicada pelo sistema de numeração, é, então, substituída por essa ordem, como que de
} 
Vejamos, sumariamente, alguns aspectos tractarianos dessas dificuldades, para melhor compreender sua solução gramatical pelo conceito de uso.

\section{AS DIFICULDADES NO ESPAÇO LÓGICO}

O estabelecimento dos pontos de contato da linguagem com o mundo é uma questão que permaneceu inexplorada no Tractatus, porque considerada fora do âmbito do campo transcendental da lógica. A reflexão lógico-filosófica tem início, no livro, já supondo que as palavras sejam aplicadas como nomes a elementos do mundo, os objetos, considerados logicamente simples. Não se investigam as formas iniciais de ligação entre os nomes e os objetos, uma vez que a necessidade dessa ligação é imposta pelo modelo lógico como uma condição $a$ priori da significação e da determinação completa do sentido: uma vez que representamos o mundo através de proposições com sentido determinável, dada a sua forma verifuncional, é necessário que haja elementos simples no mundo e na linguagem para que o vínculo interno seja estabelecido entre os dois domínios, e a análise do sentido seja completa.

Ora, os pontos de contato são atribuídos à inexplorada e, por isso, obscura, relação de substituição (Vertretung) do objeto pelo nome na proposição. Ainda que de natureza linguística, essa relação de substituição não é exprimível proposicionalmente no universo tractariano, dado que, embora seja uma

reflexos multiplicados de imagens, amplificados por vezes, ou reduzidos a detalhes, outras vezes, em um espelho que é o álbum wittgensteiniano. Assim são apresentadas cada imagem e grupos de imagens - ou melhor, temas e conjuntos de temas correlacionados - que servem como lentes para observar uns aos outros em suas complexas relações. A visão perspícua se organiza, assim, como método terapêutico. Note-se, a esse respeito, a referência a uma "rede de números" para apresentar as conexões complexas entre as observações filosóficas, feita no esboço de Prefácio de 1937 (MS 118, p. 95v) e a versão em inglês do Prefácio da primeira versão das IF (TS225) (cf.Venturinha 2010: 'A Re-evaluation of the PI' in Wittgenstein After the Nachlass, London, Palgrave Macmillan, p. 143-156), onde há também menção explícita a um sistema de numeração: “... and I shall explain the connections between my remarks, where the arrangement des not itself make them apparent, by a system of cross-references thus: each remark shall have a current number and besides this the numbers of those remarks which stand to it in important relations". condição prévia e logicamente necessária para a formação da proposição, não faz parte daquilo que a lógica pode prever a priori ( $\operatorname{Tr} \S \S 5.55-5.551)$. Em outros termos, a situação de contato entre a linguagem e o mundo comporta um nível de contingência que é excluído da expressão linguística proposicional, porque não parece haver aí formas lógicas - ou melhor, os nomes não contêm as possibilidades dos objetos que podem substituir nas proposições, tampouco os objetos as possibilidades dos nomes que podem vir a substitui-los. Nesse ponto, é introduzida a noção de aplicação do signo (Anwenung) e, por extensão, da lógica ( $T r$ §§ 3.26-3.3263, 5.557) - atividade que não pertence ao seu campo transcendental. ${ }^{2}$ Não sendo exprimível por proposições, essa situação não é provida de sentido, tampouco corresponde a uma forma lógica inexprimível.

Um dos temas centrais da autoterapia será o dogmatismo dessa concepção, por ter resultado, dirá mais tarde Wittgenstein, da projeção de propriedades do modelo lógico, que fora usado no Tractatus como sistema de referência para descrever as relações entre linguagem e mundo, sobre os conteúdos descritos (CV, 1998, p. 21e-22e). Daí, por exemplo, a situação de um contato linguisticamente inexprimível entre nome e objeto, por ser desprovido de forma lógica, apontando para uma porta que devia permanecer fechada no universo logicista do livro, a da aplicação (Anwendung) do signo como nome e, mais amplamente, da lógica (Tractatus § 5.557), (Moreno 2005, 2011, cap. 5,2I; 2007, p. 3-4). Era a porta de acesso ao ambiente pragmático de uso da linguagem, onde a descrição terapêutica, a partir do final dos anos 20, aprofundará e expandirá a exploração de diversas práticas, ou técnicas linguísticas que estabelecem as ligações iniciais entre nome e objeto - sem engajar-se em descri-

2 Seria conveniente notar, o contraste entre a relação da Verbindung proposicional com o cálculo verifuncional, e a relação da Vertretung de objetos por nomes com a Anwendung do signo e da Lógica: enquanto a combinação remete ao cálculo da forma lógica, a substituição remete à aplicação da linguagem, que é uma atividade exterior ao campo transcendental. Apesar de linguística, a relação de substituição de objetos por nomes não pode ser explorada pela análise lógica por estar situada em um campo supostamente empírico que é o da pragmática 
ções de processos empíricos e guardando sempre a herança fregeana acima salientada.

O esclarecimento conceitual prévio dessa situação simbolicamente elementar parece ser, para Wittgenstein, uma condição indispensável para o tratamento terapêutico da concepção essencialista de proposição como imagem descritiva dos fatos. De fato, na montagem do álbum, Wittgenstein o situa na apresentação dos seus primeiros esboços de paisagens.

Mas há, ainda, outro aspecto da relação da linguagem com o mundo, que permanece inexplorado no Tractatus: é o das ligações entre os nomes e entre os objetos, em proposições e em estados de coisas, respectivamente. Essa situação, todavia, contrariamente à anterior, tem forma lógica e deveria, portanto, ser passível de expressão proposicional. De fato, os objetos possuem propriedades internas, ou melhor, contêm, a priori, todas as possibilidades de combinações com outros objetos em estados de coisas ( $\mathrm{Tr}, \S \S 2.012$ 2.0121) - o mesmo devendo valer para os respectivos nomes que os substituem nas proposições. Ora, esse cálculo de combinações lógicas entre objetos, evocado no livro, não é desenvolvido por uma combinatória a priori de nomes, mas, apenas, pelo cálculo de combinações entre proposições, deixando inexplorado o espaço dos objetos - aspecto essencial do espaço lógico, pois é o fundamento da teoria da proposição e da tese da determinação completa do sentido. ${ }^{3}$ É a esse espaço que Wittgenstein atribui a função de substância do mundo, isto é, o que há de fixo e inalterável no mundo, permitindo, por isso, sua representação pela proposição significativa ( $\operatorname{Tr} \S \S$ 2.0211-2.0212). Esse parece ser um reflexo da concepção logicista

${ }^{3}$ É um espaço lógico da linguagem, mas infraproposicional, uma vez que não permite o cálculo verifuncional - a exemplo da situação linguística de substituição dos objetos pelos nomes na proposição, situação essa, na verdade, mais elementar do que a anterior e logicamente prévia a ela. Parece haver, pois, no Tractatus, uma hierarquia de diferentes situações linguísticas, relativamente à presença de formas lógicas e da aplicação do cálculo verifuncional: a substituição dos objetos por nomes na proposição, de onde estão ausentes as duas condições as combinações possíveis entre objetos, onde, apesar da forma lógica, o cálculo verifuncional não se aplica; e as combinações possíveis entre estados de coisas, onde estão presentes as duas condições. de simplicidade absoluta, que permite exprimir combinações de objetos através de proposições elementares, mas não através de combinações dos nomes que as compõem. De fato, por não ser intraproposicional, a análise lógica, no Tractatus, não permite a decomposição lógica das proposições elementares e nem, por conseguinte, o cálculo das combinações possíveis entre os objetos nelas nomeados. A proposição elementar é a unidade de sentido no espaço lógico, e é a partir dela que se inicia a aplicação da operação de negação sucessiva de proposições - não antes. A concepção de simplicidade absoluta torna inexploráveis as formas proposicionais elementares, resultantes das combinações entre os objetos no espaço lógico, assim como torna impossível fornecer um exemplo de objeto e de nome: o único critério para que uma palavra possa funcionar como nome é que ela seja aplicada a um objeto logicamente simples, assim como o único critério para que algo seja considerado como logicamente simples é que a ele seja aplicado um nome. A proposição elementar parece ter encoberto essa dificuldade ao ser considerada como a unidade linguística significativa suficiente para iniciar a exploração do espaço lógico e para a reflexão lógico-filosófica - salientando, assim, todavia, o estatuto virtual do espaço lógico dos objetos no Tractatus (Granger, 1990).

\section{AS TÉCNICAS PREPARATÓRIAS}

Seguindo essa ordem de prioridade conceitual, Wittgenstein procura esclarecer a situação, que havia permanecido ambígua, das relações entre linguagem e realidade, e inexplorada em seus dois aspectos: a substituição dos objetos por nomes e a identificação de objetos através de seus nomes. Os jogos de linguagem são o novo contexto que dará sentido ao equivalente pragmático do logicamente simples no Tractatus, permitindo esclarecer tanto as ligações elementares entre nome e objeto quanto as diversas formas de sentido presentes no uso das palavras como nomes de objetos. 
É assim que Wittgenstein descreve e comenta, em primeiro lugar, técnicas linguísticas habituais, presentes em jogos elementares da nomeação, cuja função é a de preparar jogos mais complexos, como o da descrição. Apenas em um segundo momento, Wittgenstein descreverá e comentará técnicas linguísticas, também habituais, presentes em jogos complexos, onde são construídos o sentido e a necessidade através de definições e conceitos. Na primeira etapa, as palavras são aplicadas como se fossem etiquetas, e, na segunda etapa, passam a ser aplicadas como conceitos - primeiro passo, esse, para a construção da proposição, quando a identidade do objeto é dada pela definição do conceito. É assim que, em seus primeiros esboços de paisagens, a terapia filosófica presente no álbum incide sobre a concepção de simplicidade lógica absoluta, sobre a concepção exclusivista da função referencial dos nomes e sobre a concepção da forma lógica geral e única da proposição, presentes no Tractatus (p.ex. IF §§ 10 e sgs.).

Os dois temas tractarianos centrais, do contato entre linguagem e realidade e da possibilidade de representação do mundo pela proposição significativa, que é o pensamento, são considerados, então, sob o aspecto pragmático da construção de técnicas que envolvem a linguagem e as situações de interlocução. Tais técnicas ganham o estatuto de fundamento da própria vivência da significação, tendo em vista sua expressão linguística. Como diz Wittgenstein, referindo-se às vivências de aprender a perceber aspectos e expressá-los: "O substrato dessa vivência (Erlebniss) é o dominar (Beherrschen) uma técnica (IF, II, xi).

Em primeiro lugar, a nomeação de objetos pode ser considerada como uma preparação (Vorbereitung) para jogos complexos, como, por exemplo, o jogo descritivo. De fato, a nomeação antecede a descrição, pois, com a nomeação, os objetos passam a ter nomes apenas no interior do jogo de linguagem da descrição, que, todavia, ainda não começou a ser jogado ( $I F \S 49$ ). Somente com nomes, nada podemos falar sobre os objetos - o que não significa, entretanto, que não se possa falar sobre eles por serem logicamente simples, mas só por não ter ainda sido iniciado o jogo complexo da descrição. Tudo que podemos fazer, apenas com nomes, é falar com os objetos usando, como que faticamente, seus nomes.

A introdução da ligação entre nomes e objetos ocorre por adestramento, quando a questão do sentido não pode ser colocada pelo aprendiz - ou por ele ainda não ser capaz de fazê-lo, ou por ser uma questão impertinente. Essa situação corresponde à relação de substituição do objeto pelo nome, no Tractatus, aquele primeiro passo, arbitrário e sem forma lógica, para o estabelecimento da ligação entre linguagem e mundo. Mas a ligação pode também ser ensinada por esclarecimento, ou explicação (Erklärung) do nome, ou definição do sentido, o que nos aproxima do conceito: perguntar pelo sentido do nome corresponde a procurar pela identidade do objeto através da linguagem. Assistimos Wittgenstein retomando as duas questões relativas à concepção tractariana do logicamente simples em outro contexto, agora pragmático, para tentar esclarecer as dificuldades que o ponto de vista logicista colocava sem conseguir solucionar.

O ambiente pragmático permite esclarecer que, embora de natureza causal e mecânica, o próprio aprendizado por adestramento é relativo a diversos tipos de ensino, ou contextos de uso do que é ensinado, a diferentes lições com diferentes finalidades. As mesmas técnicas de adestramento inseridas em diferentes contextos de ensino, com diferentes lições, terão diferentes resultados na compreensão e nas aplicações por parte do aprendiz (IF §§ 6,7). Não há uma simples substituição empírica do objeto pelo nome, mas relações internas de sentido, construídas através de técnicas linguísticas no interior de jogos de linguagem. Da mesma maneira, o tema do ensino ostensivo por esclarecimento, ou definição, conduz à terapia da concepção da análise completa, como se conduzisse à obtenção final do sentido logicamente simples e inanalisável (IF §§ 6-29-65 e sgs.). A terapia mostrará que são diversos os critérios de simplicidade, tanto do objeto quanto da proposição. A contextualização pragmática das ligações internas de sentido entre linguagem e mundo permite reali- 
zar a análise detalhada de sua natureza formal, sem qualquer receio de confundir-se com uma descrição empírica dos processos factuais envolvidos em sua produção - o que estava vedado no universo logicista do Tractatus - e sem deixar encoberta nenhuma etapa de sua construção - como foi o caso da relação de substituição do objeto pelo nome, assim como do espaço lógico e a priori dos objetos.

É assim que, nesse novo contexto, as várias técnicas de associação entre palavras e objetos presentes no espaço pragmático dos jogos preparatórios - como as de ostensão (ibid § 6, sgs.), as de apresentação de tabelas, etc. (IF § 8, sgs.) - têm a função de estabelecer ligações elementares de sentido entre linguagem e realidade. Wittgenstein insiste, reiteradamente, que a exploração filosófica desse espaço não é, contrariamente ao que poderia parecer, uma descrição empírica de processos que envolvem palavras, objetos e interlocutores descrição sociológica, cultural, histórica, psicológica, etc. -, ainda que exemplos empíricos de tais processos sejam a matéria bruta (raw) para a nova reflexão sobre as relações internas de sentido. Respondendo a uma objeção possível a respeito da vivência da significação - que é o que lhe interessa descrever - afirma Wittgenstein que não se trata de explicar vivências empíricas, por exemplo, de dor de dente, afirmando que sua condição lógica (logische Bedingung) (IF II, xi, p. 208e) é o dominar uma técnica. Trata-se, isso sim, de descrever a vivência da significação do conceito dor de dente no interior do jogo de linguagem da expressão de sensações, cuja técnica deve ser dominada. Assim como no caso da vivência de ver aspectos, os conceitos de vivência e de ver estão ligados à significação, e não aos conteúdos empíricos dos conceitos homônimos, aplicados aos estados psicológicos de dor e de percepção sensível (p. 208 e, sgs.). Dominar técnicas é a condição lógica, como diz Wittgenstein, para a percepção, ou compreensão, ou, ainda, para a vivência da significação - do ponto de vista da descrição terapêutica dos usos da linguagem. Os conceitos aqui em jogo são aparentados aos conceitos empíricos homólogos, mas não devem ser confundidos.
De fato, a substituição do objeto pelo nome, ou, se preferirmos, a associação entre objeto e nome, corresponde, na verdade, a um trabalho de integração significativa do mundo pelo uso da linguagem, que não se restringe apenas a estabelecer relações externas de associação mecânica ou de causalidade. Assim como, por exemplo, as diversas técnicas de etiquetagem dos objetos por nomes - como a ostensão com gestos e palavras, as correlações entre tabelas ou escalas graduadas de comprimentos, cores, temperaturas, sonoridades, etc. e objetos, através de sua combinação com instruções por meio de gestos imitativos, a pronúncia de sons, de palavras, etc. - variantes complexas da etiquetagem e da ostensão; a técnica de amostragem aplicada às palavras e aos objetos - o jogo metalinguístico da menção de elementos da linguagem e o jogo da integração de objetos à linguagem sob a forma de normas; a técnica dos retratos, dos paradigmas, etc., como variantes menos e mais complexas da criação de padrões (Maßtab). (Moreno, 2011).

Essas são algumas das técnicas que Wittgenstein descreve como fazendo parte dos processos de "ensino ostensivo das palavras" e de "definição ostensiva” - sendo que a compreensão dessas técnicas dependerá, como salientamos acima, dos contextos em que forem aplicadas e de suas finalidades, de como forem ensinadas através de uma lição (Unterricht) (IF § 6 e sgs.). A nenhum momento se trata, para Wittgenstein, de descrever processos ou experimentos de ensino e aprendizado com a finalidade de apresentar teses a esse respeito. Sua finalidade exclusiva é mostrar como o domínio dessas técnicas é uma condição para que os aprendizes compreendam, podendo, assim, seguir e inventar novas ligações internas de sentido - ao incorporarem normas à sua ação através de aplicações da linguagem ao mundo no interior de contextos que orientam essas aplicações. Dominar técnicas linguísticas é uma condição lógica, e não empírica, para termos a vivência do sentido, por exemplo, para interpretarmos uma situação de outra maneira que não a habitual - e não apenas reagirmos mecanicamente diante de 
novos estímulos -. variando os aspectos que dizemos perceber dos objetos e situações, inclusive das próprias palavras, como no jogo de vivenciar palavras (Spiel des Worterlebens) (IF, II, xi). Se não estivermos familiarizados com técnicas linguísticas, seremos, em determinadas circunstâncias, como cegos para o aspecto, ou melhor, para o sentido.

\section{AS FUNÇÕES REGULADORAE CONSTITUTIVA}

Dessa maneira, a descrição terapêutica chama-nos a atenção para duas funções características que essas técnicas exercem nos jogos de linguagem, a função reguladora e a função constitutiva. Regulam as normas para incorporar significativamente elementos do mundo à linguagem, apresentando-os como candidatos à aplicação de nomes: "isto é verde"; e, por outro lado, constituem o sentido do que é ser um objeto, apresentando-o como o contexto da aplicação do nome: "verde é uma cor”. No ambiente pragmático pós-tractariano, estas duas funções das regras serão incorporadas pelo aprendiz através do adestramento, ou ensino ostensivo de associações entre signos, e da definição ostensiva de sentidos, no interior de jogos de linguagem. E isso, como assinalamos acima, tendo como pano de fundo o trato prévio com o uso das palavras, o domínio prévio e mesmo informal, ou prático, de outros jogos de linguagem, como condição lógica para o aprendizado de novas regras.

As ligações elementares entre linguagem e mundo continuam a ser consideradas como condição de possibilidade da proposição, mas deixam de ser consideradas como relativas exclusivamente a processos empíricos inexploráveis formalmente. O novo ambiente pragmático permite detectar aspectos formais antes insuspeitados no uso da linguagem, e indicar aí as técnicas de integração do mundo ao sentido, que são práticas linguísticas, as quais poderão doravante ser exploradas e esclarecidas (erklären) - o que as exigências de pureza da análise lógica interditavam. Todavia é a própria concepção de objeto e de proposição que serão reformuladas.
De fato, para que algo possa "soar como uma proposição”, não é preciso verificar os nomes que a compõem, ainda que nomes entrem em sua composição, mas é preciso ter a familiaridade suficiente com a linguagem que permita perceber analogias e ligações de semelhança entre casos diferentes, para poder ir além das regras estabelecidas e criar novas, ou transformar as antigas. Em certos contextos de uso da linguagem, um nome pode soar como proposição e, em outros, uma proposição pode ser aplicada como nome (p.ex. IF § 27 , sgs., $\S 19$, sgs.).

É assim que podemos apreciar, no pensamento de Wittgenstein, uma nova concepção do conceito de condição de possibilidade que emerge dos processos de integração linguística da realidade e de definição do objeto. Esta concepção conserva, do conceito kantiano, a necessidade assim como a independência daquilo que condiciona, mas o torna relativo aos usos da linguagem: são condições normativas criadas a partir da aplicação de outras normas e durante o processo de uso das palavras - como diz Wittgenstein, "jogamos e 'make up the rules as we go along"' assim como “as alteramos - 'as we go along”, (IF § 83). Conserva o estatuto de condição formal e a priori, relativamente ao que condiciona, e revela o seu modo de construção e de funcionamento, que é $a$ parte post, isto é, no decurso do uso da linguagem.

Essa concepção resulta, em Wittgenstein, da terapia do essencialismo logicista e, é claro, da autoterapia, e aponta para novos horizontes: permite que se torne claro para o olhar, através do método de apresentação panorâmica das aplicações das palavras, a presença das funções reguladora e constitutiva da significação no uso das palavras respectivamente, regular a organização linguística da realidade, preparando as posições dos signos, e definir que tipo de objeto uma coisa é.

\section{ALGUNS JOGOS CONSTITUTIVOS}

Há duas imagens em torno das quais evolui o pensamento de Wittgenstein e que correspondem 
às duas concepções de linguagem e, mais amplamente, de representação (Darstellung e Vorstellung). São as imagens do mostrar (zeigen) o que não se pode dizer, e a do olhar, ver (schauen) aspectos do objeto que são encobertos pela vontade. Se a tarefa da filosofia era, no primeiro caso, a de aplicar um método único e rigoroso para mostrar o que estaria velado pela forma superficial da linguagem, no segundo caso, a tarefa será a de aplicar procedimentos terapêuticos diversos para vencer as resistências da vontade de olhar para o que está nossa frente, mas que é velado por hábitos do pensamento e pela uniformidade aparente da linguagem. Nesse segundo caso, a tarefa parece ser dupla: primeiro, persuadir, uma vez que se trata da vontade e não do intelecto, a olhar, ou a admitir outros aspectos; segundo, levar a ver, ou a compreender esses novos aspectos. A persuasão repousa no método de exibição panorâmica (übersitlich Darstellung) de diversos casos de aplicação das palavras, e a compreensão repousa sobre a familiaridade com diversas técnicas linguísticas, uma vez vencidas as resistências da vontade, por parte do interlocutor filosófico.

Após o Tractatus, de fato, Wittgenstein explora o tema da expressão linguística da percepção de novos aspectos do sentido em diferentes campos do conhecimento além do da linguagem, como matemática, lógica, psicologia, filosofia e áreas conexas, como ensino e aprendizagem, antropologia, etc. Essa questão está ligada à finalidade terapêutica da filosofia, ideia que surge no pensamento de Wittgenstein durante o início dos anos 30 e está presente na primeira parte das IF, editada pelo próprio autor. Essa mesma questão é retomada sob o ponto de vista da percepção gestáltica de boas formas, e será explorada, sobretudo, nos escritos sobre filosofia da psicologia do final dos anos 40, alguns dos quais foram editados como a segunda parte do livro, pelos herdeiros testamentários de sua obra.

Assim, os temas da percepção, compreensão ou vivência da significação e, sobretudo, de sua expressão linguística abrem um vasto campo para a descrição de regras de uso das palavras em expressões linguísticas gramaticais, relativas à per- cepção do sentido em geral. Essa vasta reflexão, iniciada no final dos anos 20, elaborada no início dos anos 30, desenvolvida e aprofundada durante a segunda metade dos anos 30 em diante, até o final de sua vida, não deixa de ecoar a voz do Tractatus quando se refere a uma Teoria do Conhecimento como Filosofia da Psicologia. Ela era entendida, então, como uma atividade de caráter formal e não empírico, de esclarecimento de conceitos envolvidos no pensamento lógico, de acordo com o projeto do grande mestre Frege. A partir do final dos anos 20, assistimos a essa vasta exploração empreendida por Wittgenstein, de acordo, então, com a nova orientação pragmática que irá tomando o seu pensamento.

Seria importante salientar que os temas da percepção, compreensão e vivência da significação estão sempre presentes no centro das descrições de usos de palavras realizadas pelo terapeuta nos diversos campos por ele explorados. Trata-se, de fato, de mostrar os diversos aspectos da significação relativos às aplicações das palavras. Este tema poderia, certamente, servir como fio condutor para organizar o vasto projeto de uma Teoria do Conhecimento como Filosofia da Psicologia, a que parece dedicar-se Wittgenstein de maneira sistemática - embora muito pouco linear, como o atestam as diversas incursões paralelas dos MSs e DTs por trilhas mais ou menos próximas, em diversas períodos, mas todas ligadas internamente por relações de semelhança e formando sistemas regrados: espaço perceptivo, espaço de cores, espaço de estados mentais, espaço de conceitos matemáticos, espaço de conceitos epistêmicos. A reflexão terapêutica percorre todos esses diferentes espaços procurando esclarecer, em cada caso, as diversas formas de compreensão da significação, através da descrição minuciosa e da apresentação panorâmica de suas expressões linguísticas. Trata-se, como vimos acima, de descrever as técnicas linguísticas de construção das regras da significação - pois são essas técnicas que devem ser dominadas pelo aprendiz para que ele possa, inclusive, perceber novas regras, novos aspectos do objeto, novas significações, isto é, para que possa compreendê-las. 
Ora, Wittgenstein acentua, em todos os casos, a função criterial das próprias expressões linguísticas - incluindo aí palavras, comportamentos, sensações, objetos do mundo exterior, interlocutores, enfim, tudo o que estiver inserido em jogos de linguagem e for incorporado como meio de apresentação da linguagem, ou melhor, como instrumento linguístico-, o que é, aliás, mais natural e permite evitar confusões (IF § 16). A significação conceitual está presente nos usos feitos de suas próprias expressões linguísticas, e não fora da linguagem, sob a forma de definições.

Vejamos, sumariamente, alguns casos de regras que norteiam a construção de expressões linguísticas normativas da percepção, que a organizam em um espaço, que poderíamos denominar, da "temporalidade gramatical" - espaço atemporal de regras de expressão. São as expressões relativas à percepção do passado, do presente e do futuro.

A partir das análises que faz Wittgenstein do problema filosófico do tempo, tal como apresentado desde Agostinho, por Russell e James, da fluência intrínseca dos acontecimentos no tempo e da centralidade do tempo presente, podemos apontar para a seguinte situação conceitual relativa aos relatos de percepções de eventos passados. Por exemplo, pode-se dizer que a palavra "sonho" é normalmente aplicada em relatos sobre o passado, em que a percepção é organizada como em estado dormente, e a palavra "recordação" para a percepção como em estado desperto. São regras do tipo: se percebi X no passado, enquanto dormia, então X é um sonho; e se percebi X no passado, estando acordado, então Xé uma recordação. Daí, as duas situações perceptivas comportarem indeterminações características - do sonho e da memória - e o seu relato deixar margem à presença da imprecisão e da imaginação (p.ex., IF, § 634; II, vii, p. 184, xi, p. 222, xiii, p. 231, etc.), pois estaremos sempre dispostos a completar e a corrigir detalhes dos respectivos relatos; eles passam, assim, a ser os únicos critérios de sua própria validade (p.ex., DW/S, p.146 sgs., 157 sgs., 166 sgs.). Ora, a indeterminação está como que prevista pela gramática do uso dos respectivos conceitos, e seria inútil procurá-la fora das regras dos relatos por exemplo, nos processos psicofisiológicos característicos do sonho e da memória. Por outro lado, não é preciso uma linguagem especial, fenomênica, para expressar diretamente a indeterminação intrínseca da percepção, sobretudo nesses casos, uma vez que a linguagem cotidiana comporta a indeterminação na definição dos próprios conceitos de sonho e recordação. Caso eliminemos a indeterminação desses conceitos, teremos outros conceitos, diremos coisas diferentes.

As regras de uso são, aqui, constitutivas da significação, pois dizem o que é sonhar e o que é recordar: os relatos do sonho e da recordação são os critérios do sonhar e do recordar - muito diferentes das reações psicofisiológicas que acompanham os processos do sonho e da recordação. Os limites do sentido são estabelecidos nas aplicações dos conceitos, isto é, o uso das expressões linguísticas determina o como e o quê é percebido no passado - e não eventos extralinguísticos do passado, percebidos em estado desperto ou no sonho. São casos em que o conceito de limite é determinado internamente aos conceitos sono e vigília - e não externamente, à imagem de uma experiência espacial do limite de uma figura (DW/ S, p. 163, sgs). A força normativa das regras de uso faz-se notar nos casos, por exemplo, em que não se conhece o estado original da percepção, se dormente ou desperta, e é introduzida a comparação com a indeterminação do estado sonhador da memória: "não mais sei se estava acordado ou sonhando ao perceber X", ou mesmo em situações de percepção atual e desperta, é possível dizer: "parece-me que estou sonhando, ao perceber este X". Nesses casos, a indeterminação característica do conceito de sonho é aplicada a situações que independem do sonhar efetivo, ou mesmo em que o sonhar está ausente. Esse é, aliás, o fundamento linguístico que permite ao cético duvidar que não esteja sempre sonhando.

Uma segunda situação de expressões linguísticas temporais é quando as palavras designam estados psicológicos que antecipam fatos. São 
vários os exemplos examinados por Wittgenstein: “expectativa que p" (erwarten), “desejo que p”, “intenção que p”, “querer dizer que p” (meinen), etc. As palavras são aplicadas em enunciados do tipo: “'X que p' é o que é satisfeito por p” independentemente da ocorrência do fato p. Não saímos da linguagem para apreender, no presente, com o pensamento, fatos futuros. Eis uma regra gramatical constitutiva que define o objeto ao dizer o que é esperar, intencionar, desejar em relação aos conteúdos que os satisfazem, como condição de sentido interna aos próprios enunciados.

Uma terceira situação de expressões linguísticas temporais é quando as palavras são aplicadas para expressar a percepção atual e desperta, como "Percebo X". As regras de uso desses enunciados são do tipo: se percebo isto como X, atualmente e estando desperto, então isto é percebido como sendo X. Por exemplo "Esta é minha mão" ou "Isto é uma mão", "Vejo que chove" ou "Chove!”, "Estou com dor de cabeça” ou "Estou com dor!", etc., são expressões de normas das descrições da percepção atual e desperta Se aprendi a aplicar o conceito X em expressões linguísticas da percepção atual e desperta, então, em condições normais, a aplicação da expressão linguística é o critério da percepção. Como comenta Wittgenstein, é sempre possível duvidar da percepção sensível, mas, então, é preciso compreender porque dela não duvidamos na vida cotidiana (IF $§ \S 354,355$ ). E a resposta é que não duvidamos porque aprendemos as convenções da linguagem da percepção. A descrição dos usos feita por Wittgenstein consiste, em grande parte, em mostrar quais são as convenções dessa linguagem, quais são as regras que orientam a construção das expressões linguísticas nos relatos da percepção em geral - atual e desperta, ou, como nos casos dos casos anteriores, da percepção sonhadora no passado e da percepção desperta no passado.

O conhecimento dessas convenções levanos a não duvidar, mesmo quando a dúvida for possível - pelo contrário, leva-nos a ter certezas em meio a todas as dúvidas que o cético pode, legitimamente, levantar. Chegamos, neste ponto, a uma consequência epistemológica importante que extrai Wittgenstein da descrição das regras de uso de proposições normativas, ou gramaticais.

Se, por um lado, em condições normais de enunciação, não duvido das convenções que definem o sentido dos conceitos aplicados na linguagem da percepção, por outro lado, e consequentemente, da mesma forma que não duvido, também não conheço os conteúdos percebidos. De fato, no caso de normas de sentido, a ausência de dúvida não implica conhecimento, mas indica apenas uma maneira de considerar as normas, a saber, considerá-las como um fundamento e não como matéria para verificação. Por exemplo, que eu sinta dores ou que esta mão seja minha, não são conhecimentos que tenho de mim próprio, uma vez que, em situações normais, não coloco minha sensação e minha mão como questões a serem investigadas, para serem verificadas ou negadas. Admito, simplesmente, que sinto dores e que esta é minha mão (IF § 246; S/C). Da mesma maneira, em condições cotidianas normais, não diria, ao relatar um sonho, que sei ter sonhado - mas, apenas, que sonhei - e nem, ao relatar algo, que sei recordar-me de minha percepção desperta - mas, apenas, que me recordo. A impertinência da dúvida, nesses casos, também não implica o conhecimento. Mesmo o cético, ao colocar em dúvida essas afirmações, não o faz com a finalidade de testar o conhecimento de fatos, mas, exclusivamente, para levar o argumento da dúvida aos limites e mostrar que não háfundamentos legítimos para o conhecimento.

Eis uma consequência epistemológica extraída por Wittgenstein da função normativa de certas regras de uso da linguagem: a certeza é uma maneira de considerar as normas de sentido, ou, ainda, é uma atitude diante das proposições normativas, a saber, considerá-las como sendo o fundamento do sentido - e, por isso, não seria pertinente negá-las. Por exemplo, "Sei que esta mão é minha”, "Sei que chove" e "Sei que sinto dores" não exprimem conhecimentos, uma vez que não podem ser falseadas em condições normais de nossa vida cotidiana; sua negação - aliás, sempre possível - não teria sentido. Seria preciso, para 
negá-las, realizar as mesmas variações que faz o próprio Wittgenstein ao longo de suas descrições do uso das palavras, introduzindo, inclusive, situações não padrão para testar a aplicação de nossos conceitos habituais e, com isso, os limites internos de sentido nos jogos de linguagem. Ao fazer isso, sua finalidade é, todavia, exclusivamente, terapêutica, não é cética. Negar tais enunciados corresponde a suspender as proposições gramaticais que delimitam o campo de sentido dos jogos de linguagem, ou melhor, corresponde a suspender o sistema de certezas que fundamentam os jogos. Esses enunciados não exprimem conteúdos cognitivos, mas normas de sentido; eles exprimem, no limite, o conhecimento das convenções linguísticas de nossa percepção - graças ao qual, como vimos, e apesar da dúvida sempre possível, agimos com certeza.

Assim, o resultado a que chega Wittgenstein com a aplicação de sua terapia filosófica não é uma tese sobre o conhecimento, mas, apenas, um esclarecimento conceitual que permite situar, com mais clareza, o estatuto teórico relativo das categorias de certeza e de conhecimento.

Essa conclusão de Wittgenstein - de que a certeza não é uma forma de conhecimento, mas a atitude que assumimos frente a certas proposições da linguagem, ao considerá-las como sendo o fundamento sem fundamento da significação - levanos, naturalmente, à ideia de explorar o conceito de uso do ponto de vista das regras que organizam e que constituem o campo do sentido. Em outros termos, leva-nos a vislumbrar o novo campo de reflexão aberto pela concepção de práxis da linguagem, em particular, de organização gramatical do pensamento e da experiência por meio da linguagem, em Wittgenstein: é o campo das condições de possibilidade do sentido instituídas a parte post, no decurso das aplicações das regras, mas com validade a priori, ou melhor, sem qualquer dependência de circunstâncias empíricas e, pelo contrário, como normas de organização de seus materiais. Desse ponto de vista, essas condições de natureza pragmática são formais, ou melhor, não expressam propriedades de objetos, mas condicionam sua for- ma de expressão pela linguagem. Eis a nova figura do transcendental, para a qual nos parece apontar a descrição terapêutica dos usos da linguagem. ${ }^{4}$

Recebido para publicação em 27 de agosto de 2012 Aceito em 04 de novembro de 2012

\section{REFERÊNCIAS}

CARNAP, R. Introduction to semantics. Harvard,USA: Harvard University Press, 1942.

GRANGER, G. G. L'espace logique dans le tractatus. In: WITTGENSTEIN, L. Invitation à la lecture de Wittgenstein.
Aix-en-Provence: Alinea, 1990.

MORENO, Arley R. Erro, ilusão, loucura. In: PRADO JR. Bento. Erro, ilusão, loucura - ensaios. São Paulo: Ed.34, 2004.

Introdução a uma pragmática filosófica. Campinas: Unicamp, 2005.

. Introduction à une epistémologie de l'usage. Paris: Ed. L’Harmattan, 2011.

Pensamento e realidade: em direção a uma pragmática filosófica. In: (Org.) Wittgenstein: aspectos pragmáticos. Campinas, 2007. (Coleção Cle, v.49).

Pensamento formal e descrição dos usos das palavras. In: . (Org.) Alguns aspectos do pensapinas, 2008. (Coleção Cle, v.58).

Pensée formelle et description de l'usage des mots. In : Paris: Ed. Hermann, 2010.

MORENO, Arley R. From satz to begriff em image and imaging in philosophy. Science and the Arts, v.1, 2011. In: INTERNATIONAL WITTGENSTEIN SYMPOSIUM IN KIRCHBERG, 33, 2010, Germany. Proceedings... Germany: ALWC, Ontos Verlag, 2011

. La description grammaticale et sa fonction transcendantale, em grammatical ou transcendantal. Cahiers de Philosophie du Langage, Paris, L'Harmattan, v.8, 2012.

MORRIS, C. Foundations of the theory of signs. In: INTERNATIONAL ENCYCOLOPEDIA OF UNIFIED SCIENCE, Chicago, v.1, n.2, 1938.

WITTGENSTEIN, JJL: BF-Bemerkungen über die Farben/ A Gramática das Cores em Wittgenstein. Trad. J.C.Salles. Campinas, São Paulo, 2002. (Coleção CLE,35).

. BT -The Big Typescript/TS213, German/English Scholar's Edition, edited. and translated by LUCKARDT, C.G.; AUE, A.E. Oxford: Blackwel,1 2005.

${ }^{4}$ Permitimo-nos referir, a esse respeito, os artigos de nossa autoria: 'Pensamento formal e descrição do uso das pa autoria: 'Pensamento formal e descrição do uso das Homenagem a Gilles-Gaston Granger, Coleção CLE, vol. 58, Campinas, 2008/ 'Pensée formelle et description de l'usage des mots' em La pensée formelle de GIles-Gaston Granger, Ed.Hermann, Paris, 2010, e 'La description grammaticale et sa fonction transcendantale', em Grammatical ou Transcendantal? , Cahiers de Philosophie du Langage, v.8, Ed.L'Harmattan, Paris, 2012. 
$B G M$ - Bemerkungen über die Grundlagen der Mathematik/Remarks on the Foundations of Mathematics, 2.ed., ed.by G.H.von Wright, R.Rhees and G.E.M.Anscombe, translated by G.E.M.Anscombe, Oxford: Blackwell, 1967.

CV - Culture and Value, revised Edition, edited by G.H.von Wright in collaboration with H.Nyman, revised by A.Pichler, translated by Peter Winch, Oxford: Blackwell, 1998.

DW/S - Dictées de Wittgenstein à Waismann et pour Moritz Schlidk, Paris, A.Soulez, v.1, PUF, 1997. (Textes inédits, années 1930).
IF - Philosophische Untersuchungen/Philosophical Investigations, 3.ed., translated by G.E.M. Anscombe. Oxford: Blackwell, 1968.

ÜC - Über Gewissheit/On Certainty, ed. by G.E.M.Anscojmbe and G.H.von Wright, translated by D.Paul and G.E.M.Anscombe, Oxford: Blackwell, 1998.

Tr - Tractatus logico-philosophicus.London: Routldge \$ Kegan Paul, 1961.

Z - Zetell, edited by G.E.M. Anscombe and G.H.von Wright, translated by G.E.M.Anscombe. Oxfor: Blackwell. 


\section{INTRODUCTION TO AN EPISTEMOLOGY OF USE}

\section{Arley Ramos Moreno}

In our text, by presenting a conception of philosophical pragmatics and taking into account a wittgensteinian exposition of the language games, we wish to show that the therapeutic description of the uses of words, through the procedure of methodological variations of their diverse applications, suggests a precious series of elements which allow for the exploration of the concept of use as indicative of a field that clarifies the epistemic activity of constitution of meaning, through the work with language and elements of the extralinguistic world. From this viewpoint, the epistemic activity would not be limited to the elaboration of cognitive models, but should be understood as constitutive of meaning in general, the cognitive forms being a mere chapter - albeit an important one - of the more general activity of constitution that defines what the object is - or better, defines its sense.

KEY-WORDS: Wittgenstein. Philosophical pragmatics. Epistemology of the use. Therapy. Grammar.

\section{INTRODUCTION A UNE ÉPISTÉMOLOGIE DE L'USAGE}

\section{Arley Ramos Moreno}

En présentant dans notre texte une conception pragmatique de la philosophie et en tenant compte de l'exposition des jeux de langage de Wittgenstein, nous avons l'intention de montrer que la description de l'usage des mots à des fins thérapeutiques, avec un procédé de variations méthodologiques de leurs diverses applications, suggère un certain nombre d'éléments précieux qui permettent l'exploration du concept d'usage comme indicatif d'un champ capable d'éclairer l'activité épistémique de constitution de la signification par le biais d'un travail avec le langage et les éléments du monde extralinguistique. De ce point de vue, l'activité épistémique ne se limiterait pas à l'élaboration de modèles cognitifs mais devrait être comprise comme un élément constitutif de la signification en général, les formes cognitives étant à peine un chapitre, important certes, de l'activité plus générale de constitution qui définit ce qu'est l'objet - ou mieux, en définit son sens.

Mots-CLÉs: Wittgenstein. Pragmatique philosophique. Epistémologie d'usage. Thérapie. Grammaire.

Arley Ramos Moreno - Doutor em Filosofia. Professor titular da Universidade Estadual de Campinas. Pesquisador do CNPq. Tem experiência na área de Filosofia, com ênfase em História da Filosofia, atuando principalmente nos seguintes temas: Filosofia da Linguagem, Epistemologia, Wittgenstein e Pragmática filosófica. Publicações recentes: Grammatical ou Transcendantal. Paris: LHarmattan, 2012. v. 8. 232p; Image and Imaging in Philosophy, Science and the Arts. Ontos Verlag, 2011, v. 1, p. 73-108. 
